\title{
Measurement of Organizational Performance: Empirical Evidence on Manufacturing Companies in Indonesia
}

\author{
Nanik Wahyuni ${ }^{1}$, Boge Triatmanto ${ }^{2, *}$, Isnan Murdiansyah $^{3}$ \\ ${ }^{1,3}$ UIN Maulana Malik Ibrahim, Malang, Indonesia \\ ${ }^{2}$ University of Merdeka Malang, Indonesia \\ *Corresponding author. Email: boge.triatmanto@unmer.ac.id
}

\begin{abstract}
This study aims to measure organizational performance as the impact of environmental changes by considering management accounting practices in manufacturing companies in Indonesia. This study develops contingency theory and institutional theory as a basis for analyzing the effect of environmental changes on the performance of manufacturing companies in Indonesia, both directly and indirectly, through changes in management accounting practices, which is responsible for company performance. The sample is randomly determined by 149 managers. Primary data using a questionnaire was collected by email, postal mail, or went directly to the manager. Data analysis was performed with Partial Least Square (PLS). The results of this study found that environmental changes have no effect on improving organizational performance, but environmental changes affect the change in management accounting practices. In contrast, changes in management accounting affect organizational performance. It means that changes in management accounting are able to mediate environmental changes to improve organizational performance.
\end{abstract}

Keywords: environment uncertainty, changes of management accounting practices, organizational performance

\section{INTRODUCTION}

Company performance is one indicator of company success that must be measured, reported and accounted for by company management [1]. The main purpose of performance measurement is to encourage management to be more proactive in running their company, so that company goals can be achieved. Company performance can be measured using financial and non-financial performance. Financial performance measurement is a measurement method using financial measures that use financial ratios as a benchmark [2], focus on the short term, and measure past performance [3], but the results of these performance measurements are not sufficient as a basis for decision making, planning, and control for managers in conditions of high competition.

The company's performance will be affected by environmental changes. A competitive environment will cause companies to focus more on implementing strategies in management accounting practices [4]. A high level of environmental uncertainty marked by technological advances will lead to changes in management accounting practices [5][6][7][8][9].

Management accounting becomes very important in the era of globalization, especially for companies that are faced with intense competition both with similar companies and other industries. Management accounting is more than just a set of techniques, but must also pay attention to a set of values and norms that provide information in the decision-making process, especially for the development of manufacturing companies [8]. Every part of the company must be consistent and support each other to strengthen management accounting systems, strategies, and structures in order to achieve competitive advantage and improve performance [10]. Management is required to be able to manage and control the company so that the company's goals can be achieved through changes that occur in management accounting practices. 
Indonesia can be categorized as a country with high environmental uncertainty, with high rates of change and opportunities for economic growth. Fluctuations in interest rates, inflation, exchange rates, and the stock exchange index, is evidence of the rapidly changing business environment in Indonesia. High economic uncertainty is an important cause of changes in management accounting practices [11].

\subsection{Organizational Performance Manufacturing Companies in Indonesia}

The manufacturing company is a company that is quite unique and has a complex work capacity starting from the production process to finished goods that are ready for sale. Manufacturing companies make a large contribution to gross domestic product (GDP). According to the Central Bureau of Statistics (BPS), there are 4 sectors that contributed greatly $(>10 \%)$ to the Gross Domestic Product (GDP) in 2016, namely: the manufacturing industry sector $(20.5 \%)$, the agricultural sector (13.5\%), the trade sector and car and motorcycle repair $(13.2 \%)$ and the construction sector $(10.4 \%)$. Of the 4 sectors that contributed greatly to GDP above, only the agricultural sector (growing $7.1 \%$ ) and the construction sector (growing 6.3\%) grew above GDP growth; while the manufacturing sector grew only $4.2 \%$, the trade and car and motorcycle repair sectors grew only $4.7 \%$. So GDP growth in 2017 has not been able to reach the target of $5.3 \%$. This phenomenon is suspected, among others, by the inability of management in anticipating changes that occur in the internal and external environment of the organization. Management's inability to anticipate these changes can be caused partly by the company's inability to manage the information available for use in making the right decision. Management accounting information system as an important instrument that supports management to manage information, so that the information presented is relevant and long-term (future) for the benefit of management.

\subsection{Environmental Change}

The environment can be broadly characterized as a phenomenon outside the organization that has both potential and actual influence on the organization. The external environment is meant here are matters relating to technology, law, politics, economics, culture, and demographics. Environmental uncertainty, which is influenced by high levels of competition, is an important contextual variable in contingency-based research. The competitive environment and technological advances, in general, have influenced manufacturing companies in changing management accounting practices, corporate designs, and strategies.

Environment refers to intense price competition or potential competitors [12][13][14]. Several studies have identified that companies in a competitive business environment tend to make changes in management accounting practices, organizational structure, and strategy [4][11][12][13][15][16]. This is also proven by Luther and Longden (2001) that the ability of organizations in conducting international trade and competing with imported goods is capable of changing management and business practices and forcing changes in management accounting practices.

Baines \& Langfield-Smith (2003) have identified a competitive environment, technology, and strategy as drivers of structural change, but did not include the role of management accounting systems in structural change. Haldma \& Lääts (2002) found an organizational structure to be one aspect of the organization that influences changes in management accounting practices. The application of a management accounting system that is supported by an appropriate business strategy will affect competitive advantage and organizational performance [18]. Other variables that affect organizational performance are the implementation of company processes and administrative functions that are supported by strategic priorities. The use of more advanced management accounting techniques can help employees to focus more on achieving differentiation strategies, such as quality, delivery, customer service to meet customer needs. For example, target costing helps managers to focus on low costs while maintaining customer expectations in the areas of quality and functionality. Management accounting systems are used as differentiation in management systems. From a business policy perspective, system differentiation can be used as a basis for determining competitive strategies [19].

\subsection{Change in Management Accounting Practices}

Changes in organizational environmental factors have a significant impact on accounting systems $[4][12][14][16][20]$. While the competitive environment and technology are the main triggers in changing management accounting practices [4][12][21]. This is based on the argument that under conditions of environmental uncertainty, managers need management accounting information which is specialized in decision making and helps in monitoring the development of organizational strategies.

The effectiveness and efficiency of management accounting and control systems (MACS) are important for the survival of the organization; this is evidenced by improved quality and better customer service. The company will be able to maintain its competitiveness by continuously monitoring various factors such as price competition and market share, marketing and product competition, the number of competitors, and 
competitor behavior, as well as company performance achievements through the use of management accounting systems [14][22].

Some management accounting research has highlighted significant changes in management accounting practices for example [20][23][24] which will influence system choices and effective management accounting techniques [9][25] by reconsidering design and strategy [4] in maintaining and / or improving performance [15][26][27].

High environmental uncertainty requires specific accounting information to establish strategies to support the decision-making needs of managers. This is supported by management accounting research, which states that there is a fit between the environment and organizational systems needed to change management accounting systems and to support managers about information needs [6][17][28][29]. Meanwhile, changes in environmental factors surrounding an organization can have a significant impact on management accounting systems [1][4][23][30][31].

N. Waweru, (2008) state that there are several factors that can affect changes in the organization in the face of competition, technology, new shareholders, new customers, new accountants, and poor financial performance. Whereas marketing competition and technological progress as the main triggers of management accounting changes [4][12][32]. In responding to the changing competitive environment, it is important for companies to focus on improving the quality of production and customer service. Effectiveness and efficiency MAS is an important tool for companies to remain competitive [1].

Previous research states that organizations can change MAS to systems that are more effective and efficient in overcoming high market competition [4][14][17]. The introduction of new technology will lead to a manufacturing cost structure. Computer technology causes direct labor and inventory to disappear from the factory, so the speed of operation is determined by the type of automation and manufacturing system used, and not by how fast the operator can work. As a result, the traditional cost control system itself cannot help managers to manage resources and identify relevant costs. Choe, (2004), in his study of Korean manufacturing companies, found a significant positive relationship between advanced manufacturing technology and the amount of information produced by management accounting information systems.

Several studies have shown that there is a relationship between more advanced management accounting practices, such as quality improvement, benchmarking and activity-based management (ABM) programs, and non-financial performance [4][28].
Hiebl et al., (2013) argue that there is a positive relationship between management accounting practices in the flexibility of the manufacturing environment with non-financial performance. There was a significant positive effect between TQM practices, management accounting information, and organizational performance, while [13] suggested that there was a direct influence between the intensity of market competition and business unit performance through the use of management accounting information.

Based on the description of the results of previous studies, note that changes in management accounting practices and innovation in organizations under conditions of uncertainty in the business environment affect organizational performance. Laitinen (2006) shows that changes in management accounting systems will affect financial performance.

\section{METHODS}

This study uses a survey method that is gathering information from a fairly large population. This research was conducted with a quantitative approach (positivism) to answer the problem formulation, the variables studied were quantitative, and the data collection process used a perspective approach to facilitate measurement.

The unit of analysis intended in this study is individuals who work and have mid-level managerial positions in manufacturing companies in East Java. Researchers took five individuals per company so that the total population of 1945 individuals. Large sample size was carried out to anticipate the low number of questionnaires returning and being processed. The research questionnaire was used in the study, and the questionnaire was sent directly to respondents directly through surveyors and by email to 389 manufacturing companies. The analytical tool used to test the hypothesis is Smart Partial Least Square (Smart PLS), considering that one of the variables has a formative relationship to the indicator.

The data from this study were taken from survey data, which is a unit of research analysis, namely individuals who work and have mid-level positions and large manufacturing companies in East Java. Middlelevel and above positions in question are individual positions in the company as department managers/section heads/supervisors. According to the Central Statistics Agency (BPS), large manufacturing companies are manufacturing companies that have more than 100 employees. That is, there are companies with various business fields totaling 1266 companies. After further analysis, the number of manufacturing companies in East Java that carried out the production 
process and processed raw materials into finished goods was 389 companies.

The unit of analysis intended in this study is the company, while the observation unit of this study is individuals who work and have a mid to upper-level position in manufacturing companies in East Java. Researchers took five (5) individuals per company so that the total population was 1945 individuals. A large number of samples were conducted to anticipate the low number of questionnaires that were returned and could be processed. Of this amount, the amount collected and can be processed is 149 .

Researchers conducted a pilot test on the instruments used in this study. Pilot tests are given to company managers in Malang, Surabaya, and Pasuruan. There are 40 middle-level managers who have been sampled in the pilot test. This pilot test is carried out to convince researchers that the instruments used by researchers are valid and reliable. Of the 40 questionnaires distributed and returned, only 30 questionnaires could be processed.

\section{RESULTS}

The result of the structural model (inner model) testing can be seen in R-square (R2) for the dependent construct, path coefficients, and t-value of each path. The coefficient and $t$-value of each path will be explained in the hypothesis testing. R2 is used to measure the level of variation of the independent variable changes to the dependent variable. The higher the value of $\mathrm{R} 2$ means, the better the predicted model compared to the proposed model.

The results of $\mathrm{R}^{2}$ are presented in Table 1 . The $\mathrm{R}^{2}$ for performance is 0.391 ; the value indicates that organizational performance can be explained by the environmental changes and the changes in accounting management practices by $39.1 \%$, while the rest is explained by other variables.

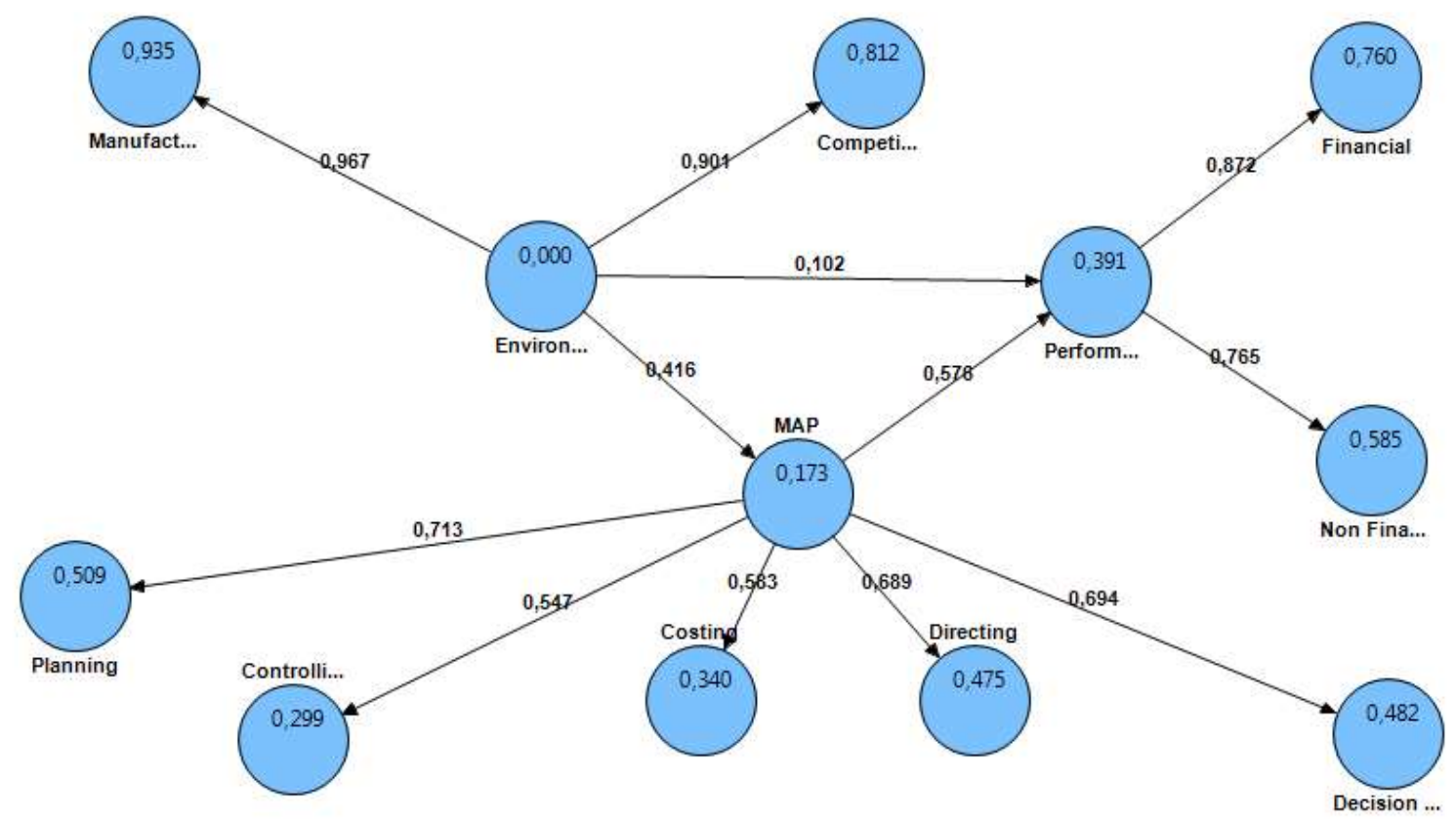

Figure 1. Hypothesis Model

Table 1. The Results of R-Square

\begin{tabular}{ccc}
\hline No & Dependent Variable & $\mathrm{R}^{2}$ \\
\hline 1 & Accounting Management & 0.173 \\
2 & Performance & 0.391 \\
\hline
\end{tabular}


The calculation results show the Q2 value for the inner model of 0.496 , which means that this model has a large predictive relevance because the value is greater than zero, so it is feasible to be used for hypothesis testing.

\subsection{The Goodness of Fit Index and Predictive Relevance}

The GoF index for this model is 0.464 . Thus, the structural model, by adding the mediating variable, has good prediction power (fit).

\subsection{Inner Model}

This study used a $95 \%$ confidence level (alpha $5 \%$ ) or t-table of 1.96 for two-tailed tests.

\subsection{Hypothesis Testing Results}

H1 states that environmental changes have a positive effect on organizational performance. In this study, environmental changes to organizational performance have a coefficient with a positive direction; the path coefficient is 0.102 with t-statistics of $1.371<1.96$, which means that environmental changes have no significant effect on organizational performance, so H1 is not supported.

$\mathrm{H} 2$ states that environmental changes have a positive effect on changes in management accounting practices. In this study, the relationship shows a coefficient with a positive direction; the path coefficient is 0.416 with tstatistics of $4.662>1.96$, which means that environmental changes have a significant effect on management accounting practices, so $\mathbf{H} 2$ is supported.

H3 states that changes in management accounting practices have a positive effect on performance. In this study, the relationship shows a coefficient with a positive direction; the path coefficient is 0.576 with $\mathrm{t}$-statistics of $7.778>1.96$, which means that changes in management accounting practices have a significant effect on performance, so $\mathbf{H 3}$ is supported.

H4 states that changes in management accounting practices can mediate the effect of environmental changes toward the performance; the relationship shows a positive effect on performance. The path coefficients both show a significant result, so $\mathbf{H 4}$ is supported.

Table 2. The Goodness of Fit (GoF) Index

\begin{tabular}{clcc}
\hline No & \multicolumn{1}{c}{ Variable } & Communality & $\mathrm{R}^{2}$ \\
\hline 1 & Environment & 0.482 & - \\
2 & Management Accounting & 0.292 & 0.173 \\
3 & Performance & 0.366 & 0.391 \\
\hline \multirow{2}{*}{} & Total & 1.571 & 0.564 \\
& Averae & 0.393 & 0.282 \\
& The Goodness of Fit (GoF) & 0.333 &
\end{tabular}

Table 3. The Results of Path Analysis on the Inner Model

\begin{tabular}{|c|c|c|c|c|c|}
\hline No & Relationship & $\begin{array}{c}\text { Path } \\
\text { Coefficient }\end{array}$ & $\begin{array}{l}\text { Standard } \\
\text { Deviation }\end{array}$ & t-Statistics & $\mathrm{P}$ \\
\hline & Variables & & & & \\
\hline 1 & Environment $->$ Performance & 0.102 & 0.075 & 1.371 & 0.170 \\
\hline 2 & $\begin{array}{c}\text { Environment }->\text { Accounting } \\
\text { Management }\end{array}$ & 0.416 & 0.089 & 4.662 & 0.000 \\
\hline 4 & $\begin{array}{c}\text { Accounting Management -> } \\
\text { Performance }\end{array}$ & 0.576 & 0.074 & 7.778 & 0.000 \\
\hline
\end{tabular}




\section{DISCUSSION}

Environmental changes affect the change in management accounting practices. Changes in management accounting practices are alleged from changes in planning, controlling, costs, performance evaluation, as well as decision making. This means that environmental changes in manufacturing companies in Indonesia with a high level of competition and technological changes have an impact on the application of management accounting practices. Changes in accounting management practices are largely determined by planning and individual performance evaluation. In addition, it is also determined by costs, control, and decision-making.

The results of this study support the results of the study by Luther \& Longden, (2002) that environmental and technological uncertainties are closely related to changes in accounting management practices. The contingency factors, including environmental changes, are supportive of changes in management accounting practices [12]. Other research conducted by Burns and Scapens (2000) and Shield (1997) confirm that environmental changes lead to changes in management accounting practices. Choe (2004) also supports the results of this study that there is a significant positive relationship between advanced manufacturing technology with the amount of information generated by management accounting information systems.

It is revealed that in a changing environment, the market has become competitive, especially in terms of quality improvement and price competition. The company's reaction to competitive environmental change and rapidly growing technology is to have a considerable investment in manufacturing technologies such as integrated computerization. Based on this, environmental changes around the organization have a significant impact on the management accounting system.

Changes in accounting management practices are a new phenomenon in management accounting that indicates a lack of uniformity in the application in every organization or company. This difference is due to the adjustment of changes in the environment. This is in line with those proposed by Burns and Scapens (2000) that environmental factors, both external and internal, have influenced the latest development of management accounting systems. Furthermore, changes in management accounting practices can improve the performance of organizations.

Changes in management accounting practices conducted by manufacturing companies affect the performance of the company, both financial performance, and non-financial performance. Environmental changes affect management accounting practices, so changes in management accounting practices are able to mediate the impact of environmental changes on organizational performance. Improved organizational performance through the changes in management accounting practices is suspected to happen by changes in planning that has a higher loading factor value compared with other indicators. In addition, individual performance evaluation indicators have the second-highest value, followed by indicators of decisionmaking, cost, and control. Environmental changes that occur in manufacturing companies in Indonesia will provide environmental uncertainty and a high risk of changes in management accounting practices.

This indicates that management accounting has moved forward and started to make changes; it is not just carrying out management accounting functions alone, but it has taken into account the business orientation in decision making to be able to improve the performance of the company. Positive results of the effect of changes in management accounting practices on organizational performance support this research. The results of this study suggest that if the change in management accounting practices coupled with accurate accounting information, it will improve performance.

Ling Lee and Yang (2011) state that changes in management accounting practices as management decision-making materials are able to improve performance. The results of other studies suggest a direct relationship between changes in management accounting practices to performance [9].

\section{CONCLUSIONS}

The success of manufacturing companies in Indonesia in improving performance is determined by many factors. In this study, the performance is reviewed from the influence of environmental changes and changes in management accounting practices. Environmental changes are hypothesized to directly affect organizational performance, as well as mediated by changes in accounting management practices. The analysis results show a direct effect of environmental changes on organizational performance. However, improvements in organizational performance will be greater if changes are made in management accounting practices.

Performance in this study is represented by financial performance and non-financial performance. The improved performance of manufacturing companies in Indonesia is determined by accounting management practices. The results of the analysis show a direct effect of environmental changes on organizational performance. However, improved organizational performance will be higher if mediated by changes in accounting management practices.

The results show that the performance of manufacturing companies in Indonesia can be improved by making changes in accounting management practices. The performance of the organizations observed in this 
study includes financial performance and non-financial performance. The results of the analysis indicate the direct influence of environmental changes on organizational performance, but the improvement of organizational performance will be greater if mediated by changes in accounting management practices. It is, therefore, advisable for managers that environmental changes, characterized by high competition levels and technological changes, should be followed by the adoption of more intensive management accounting practices.

\section{REFERENCES}

[1] Z. Hoque, "Market Competition, Computer-Aided Manufacturing And Use Of Multiple Performance Measures : An Empirical Study," no. March 2000, pp. 23-45, 2001.

[2] E. K. Laitinen, Effect of reorganization actions on the financial performance of small entrepreneurial distressed firms, vol. 7, no. 1. 2011.

[3] R. Jusoh, D. N. Ibrahim, and Y. Zainuddin, "The performance consequence of multiple performance measures usage: Evidence from the Malaysian manufacturers," Int. J. Product. Perform. Manag., vol. 57, no. 2, pp. 119-136, 2008.

[4] A. Baines and K. Langfield-Smith, "Antecedents to management accounting change: A structural equation approach," Accounting, Organ. Soc., vol. 28, no. 7-8, pp. 675-698, 2003.

[5] J. Burns and R. W. Scapens, "Conceptualizing management accounting change: an institutional framework," no. November 1998, pp. 3-25, 2000.

[6] E. Waweru, Nelson; Uliana, "Predicting change in management accounting systems: a contingent approach," Probl. Perspect. Manag., vol. 6, no. 2, pp. 72-84, 2008.

[7] L. Gani and J. Jermias, "Investigating the effect of board independence on performance across different strategies," Int. J. Account., vol. 41, no. 3, pp. 295314, 2006.

[8] T. Z. Tuan Mat, M. Smith, and H. Djajadikerta, "Determinants of Management Accounting Control System in Malaysian Manufacturing Companies," Asian J. Account. Gov., vol. 1, no. 1, pp. 79-104, 2016.

[9] N. Wahyuni and B. Triatmanto, "The effect of the organizational change on company performance mediated by changes in management accounting practices," Accounting, vol. 6, no. 4, pp. 581-588, 2020.
[10] K. Moores and S. Yuen, "Management accounting systems and organizational con ${ }^{\circledR}$ guration : a lifecycle perspective," vol. 26, pp. 351-353, 2001.

[11] R. G. Luther and S. Longden, "Management accounting in companies adapting to structural change and volatility in transition economies: a South African study," no. May 2001, pp. 299-320, 2002.

[12] J. Bisbe, J. M. Batista-Foguet, and R. Chenhall, "Defining management accounting constructs: A methodological note on the risks of conceptual misspecification," Accounting, Organ. Soc., vol. 32, no. 7-8, pp. 789-820, 2007.

[13] S. L. Clarke and E. S. Rhodes, "Entrepreneurial apologies: The mediating role of forgiveness on future cooperation," J. Bus. Ventur. Insights, vol. 13, no. October 2019, p. e00147, 2020.

[14] J. Bell and Z. Hoque, "GAOC 2008 conference issue: Accounting's role in organizational change," J. Account. Organ. Chang., vol. 5, no. 2, pp. 133138, 2009.

[15] R. H. and D. M. Chenhall, "The Impact of Structure, Environment, and Interdependence on the Perceived Usefulness of Management Accounting Systems," Account. Rev., vol. 61, no. 1, pp. 16-35, 1986.

[16] N. M. Waweru and E. Uliana, "Predictors of management accounting change in South Africa: Evidence from five retail companies Predictors of management accounting change in South Africa: Evidence from five retail companies," vol. 1954, no. March, 2016.

[17] T. Haldma and K. Lääts, "Contingencies influencing the management accounting practices of Estonian manufacturing companies," pp. 379-400, 2002.

[18] R. Simons, "CONTROL SYSTEMS AND BUSINESS STRATEGY: In this study, control systems refer to formalized procedures and systems that use information to maintain or alter patterns in organizational activity. Within the dom," vol. 12, no. 4, pp. 357-374, 1987.

[19] W. Seal, "Management accounting and the challenge of strategic focus," no. March 2000, pp. 487-506, 2001.

[20] J. and F. M. Innes, "A Survey of activity-based costing in the U.K.'s largest companies," Manag. Account. Res., vol. 6, no. 1995, pp. 137-153, 1995.

[21] M. Lévesque and D. A. Shepherd, 'Entrepreneurs' choice of entry strategy in emerging and developed markets,” J. Bus. Ventur., vol. 19, no. 1, pp. 29-54, 2004. 
[22] N. Bacon and K. Hoque, "HRM in the SME sector: Valuable employees and coercive networks," Int. J. Hum. Resour. Manag., vol. 16, no. 11, pp. 19761999, 2005.

[23] J. Burns and R. W. Scapens, "Conceptualizing management accounting change: An institutional framework," Manag. Account. Res., vol. 11, no. 1, pp. 3-25, 2000.

[24] M. Kamal Hassan, "Management accounting and organisational change: an institutional perspective," J. Account. Organ. Chang., vol. 1, no. 2, pp. 125$140,2005$.

[25] N. Wahyuni and Y. H. S. Putra, "Towards understanding changes in management accounting in the manufacturing industry in Indonesia," Accounting, vol. 6, no. 7, pp. 1245-1252, 2020.

[26] J. Choe, "information and AMT on organizational," pp. 203-214, 2004.

[27] R. C. Mia, Lokman, "The Usefulness Of Management Accounting Systems, Functional Differentiation And Managerial Effectiveness," Accounttn\& Organ. Soc., vol. 19, no. 1, pp. 1-13, 1994.

[28] R. H. and K. L.-S. CHENHALL, "The relationship between strategic priorities, management techniques and management accounting: An empirical investigation using a systems approach," Accounting, Organ. Soc., vol. 23, no. 3, pp. 243264, 1998.

[29] J. Gerdin and J. Greve, "Forms of contingency fit in management accounting research - A critical review," Accounting, Organ. Soc., vol. 29, no. 3-4, pp. 303-326, 2004.

[30] J. Innes, F. Mitchell, and D. Sinclair, "Activitybased costing in the U. K .' s largest companies : a comparison of 1994 and 1999 survey results," no. May, pp. 349-362, 2000.

[31] M. Smith and H. Djajadikerta, "Management Accounting and Organisational Change: An Exploratory Study in Malaysian Manufacturing Firms,” J. Appl. Manag. Account. Res., vol. 8, no. 2, pp. 51-80, 2010.

[32] N. Waweru, "Predicting Change in Management Accounting Systems: The Effects of Competitive Strategy,” Glob. J. Bus. Res. GJBR, vol. 2, no. 1, pp. 25-41, 2008.

[33] M. R. W. Hiebl, B. Feldbauer-Durstmüller, and C. Duller, The changing role of management accounting in the transition from a family business to a non-family business, vol. 9, no. 2. 2013. 